\title{
A retrospective study on the oral health of patients in the intesive care unit
}

\author{
Um estudo retrospectivo sobre a condição bucal de pacientes em unidade de terapia \\ intensiva
}

Laura Gusmão Soares Diamantino ${ }^{1}$, Briana Góes Monteiro², Juliana Borges de Lima Dantas ${ }^{3}$, Sílvia Regina de Almeida Reis ${ }^{4}$, Alena Ribeiro Alves Peixoto Medrado ${ }^{5 *}$

\begin{abstract}
${ }^{1}$ Graduanda do Curso de Odontologia - Escola Bahiana de Medicina e Saúde Pública; ${ }^{2}$ Especialista em Cirurgia e Traumatologia Buco-Maxilo Facial - Escola Bahiana de Medicina e Saúde Pública; ${ }^{3}$ Mestre em Estomatologia - Escola Bahiana de Medicina e Saúde Pública. Professora da Faculdade Adventista da Bahia; ${ }^{4}$ Doutora em Patologia. Professora Adjunto da Escola Bahiana de Medicina e Saúde Pública; 5 Pós-doutora em Patologia Humana. Professora Adjunto da Escola Bahiana de Medicina e Saúde Pública.
\end{abstract}

\begin{abstract}
Introduction: the oral condition of patients in the Intensive Care Unit (ICU) is extremely important for clinical status monitoring, as lesions in the oral mucosa may imply complications and worsening of the health status of these patients. A higher probability of adherence, colonization, and bacterial infection in the oral cavity of patients in the ICU has also been reported. The poor oral hygiene conditions of these patients may be related to the reduction of salivary flow and difficulties in maintaining oral hygiene in a hospital environment, which rarely employs dentists on staff. Objective: to analyze the dental condition of patients admitted to the ICU of Roberto Santos General Hospital, Salvador, Bahia, Brazil. Methodology: a total of 73 patients were evaluated through an oral examination performed with a wooden spatula and sterile gauze under natural light, and data were collected and analyzed. Results: The most commom oral lesions were tongue-coating (41\%) and ulcerations in the oral mucosa caused by trauma or dehydration (19.1\%). The occurrence of pseudomembranous candidiasis (8.2\%), dehydration of the lips and mucosa (26\%), and angular cheilitis (9.5\%) was additionally recorded. It was observed that $31.5 \%$ patients had more than 10 days of hospitalization and of these, $26 \%$ presented pseudomembranous candidiasis. This clinical condition was not seen in patients with a shorter hospital stay. Conclusions: this study suggest a possible association between the length of stay of these patients and the clinical conditions presented. Thus, the results of this study may guide preventive and curative measures implemented by dental surgeons who may, in the future, be part of the multidisciplinary team of professionals working in the hospital environment, especially in ICUs.

Keywords: Intensive care units. Dental service. Hospital. Candidiasis, oral.
\end{abstract}

\begin{abstract}
Resumo
Introdução: a condição oral de pacientes internados em Unidade de Terapia Intensiva (UTI) é de extrema importância na evolução do quadro clínico desta população, já que lesões na mucosa oral podem implicar em complicações e agravo do estado de saúde destes indivíduos. Tem sido relatado também maior probabilidade de aderência, colonização e infecção bacteriana na cavidade oral de pacientes que se encontram em leitos de UTI. As condições precárias de higiene oral que estes pacientes normalmente apresentam podem estar relacionadas à redução do fluxo salivar e às dificuldades de higienização oral inerentes ao ambiente hospitalar, o qual geralmente não conta com cirurgiões-dentistas integrando a equipe de profissionais da instituição. Objetivo: a presente pesquisa visou analisar a condição odontológica de pacientes internados na Unidade de Terapia Intensiva do Hospital Geral Roberto Santos. Metodologia: setenta e três foram avaliados através de um exame bucal, realizado com espátula de madeira e gaze estéril sob a iluminação de luz natural e seus dados foram coletados e analisados. Resultados: as lesões orais mais comuns foram saburra lingual (41\%) e ulcerações na mucosa oral provocadas por trauma ou ressecamento (19,1\%). A ocorrência de candidíase pseudomembranosa ( $8,2 \%)$, lábios e mucosas desidratados (26\%) e queilite angular foi adicionalmente registrada. Foi observado que dos 31,5\% dos pacientes com mais de 10 dias de internação, $26 \%$ apresentaram candidíase pseudomembranosa. Essa condição clínica não foi observada em pacientes com menor tempo de internação. Conclusão: o presente estudo sugere uma possível associação entre o tempo de internação destes pacientes e as condições clínicas apresentadas. Desta forma, a descrição dos resultados desta investigação pode contribuir para nortear os cuidados preventivos e curativos a serem adotados por cirurgiões-dentistas que futuramente integrem a equipe multidisciplinar de profissionais que atuam no ambiente hospitalar, em especial, nas unidades de terapia intensiva.

Palavras-chave: Unidades de terapia intensiva. Unidade hospitalar de odontologia. Candidíase bucal.
\end{abstract}

\section{INTRODUCTION}

Correspondente/Corresponding: *Alena Ribeiro Alves Peixoto Medrado - End: Rua Rodolfo Coelho Cavalcante 90/502. Jardim Armação - Salvador-Bahia. CEP 41750-166. - Email: alenamedrado@hotmail.com - Tel:
The oral condition of patients admitted to the Intensive Care Unit (ICU) is extremely important for the evolution of their clinical condition, since oral mucosa lesions may lead to complications and exacerbation of their health status. In fact, a greater probability of bacterial adherence, colonization, and infection in the oral cavity has 
been reported for ICU patients (HSU et al., 2010). During intubation, oral microbiota and dental biofilm may be introduced into the lower respiratory tract by aspiration and may contribute to the development of other pathologies, such as ventilator-associated pneumonia (VAP) (CRUZ; MORAIS; TREVISANI, 2014).

According to Buischi; Axelsson and Siqueira (2000), the occurrence of VAP is worrying, as this condition is quite common in ICU patients and causes a significant increase in the number of deaths, while prolonging the hospitalization period and requiring more medication and care. In addition to bacterial infections, it is common for ICU patients to develop fungal infections. A paper evaluating this aspect composed in Iran by Badiee; Alborzi and Joukar (2011) demonstrated that candidiasis was one of the most prevalent fungal infections in this population. According to Batista et al. (2014), fungal adherence, especially by Candida albicans species, would be facilitated by low $\mathrm{pH}$, poor oral hygiene, low salivary flow, and interactions with the commensal microbiota.

In a study by Baeder et al. (2012), the authors demonstrated that the majority of patients admitted to the ICU had a poor dental condition. Such poor oral hygiene conditions may be related to the reduction of salivary flow and cough reflex, as well as to the oral hygiene difficulties inherent in the hospital environment, which generally does not include dental surgeons on the professional team of the institution (CRUZ; MORAIS; TREVISANI, 2014). The absence of adequate salivary flow in this population presents as hyposalivation, which contributes to the development of oral mucositis and oropharyngeal colonization by gram-negative bacteria (DENNESEN et al., 2003). Moreover, according to Morais et al. (2006), the significantly higher amount of dental biofilm in ICU patients may be directly related to the length of stay.

Although there are protocols adopted by nursing professionals in ICUs that aim to minimize the consequences of poor oral hygiene, such as the administration of green tea and chlorhexidine in intubated patients to control the dental biofilm (ALJA'AFRESH; MOSLEH and HABASHMEH, 2018; KHANCHEMEHR et al., 2018) oral care has been defined as inconsistent and incipient (DENNESEN et al., 2003). In fact, the development of hospital dentistry in America began in the mid-nineteenth century (GOMES; ESTEVES, 2012), but the role of the dental surgeon in the hospital environment is a recent perspective in the Brazilian context (EUZÉBIO et al., 2013) and was regulated by the bill 363, 2011, which established the mandatory presence of dental professionals in ICUS (DIB, 2011).

A study by Kahn, et al. (2008) revealed that $53 \%$ of the 62 hospitals surveyed in the state of Rio de Janeiro did not perform oral cavity evaluation, while in $85 \%$ of the sample, there was no protocol for plaque control. Given this reality, the inclusion of the dental surgeon in the multidisciplinary team of health professionals who serve this population could have a positive impact on the management of their oral needs and control of possible nosocomial infections.

Several studies point out the importance of oral care in the ICU (MORAIS et al., 2006; GOMES; ESTEVES, 2012; SCHLESENER; ROSA; RAUPP, 2012). However, there are still a few studies reporting the emergence of oral mucosa lesions in hospitalized patients. Thus, the present study aimed to evaluate the oral condition and presence of soft tissue lesions in patients admitted to a referral ICU in the state of Bahia, Brazil, linked to the Unified Health System (Sistema Único de Saúde).

\section{METHODOLOGY}

This study was submitted to and accepted by the Human Ethics Committee of the Escola Bahiana de Medicina e Saúde Pública through CAAE 67123517.1.0000.5544. A qualitative and quantitative cross-sectional observational study was carried out, through a period of 12 months, between 2017 and 2018, whose sample consisted of patients admitted to the General Intensive Care Unit of the General Hospital Roberto Santos, Salvador, Bahia, Brazil, users of the Unified Health System.

The participants were presented with an Informed Consent Form to decide whether or not they would agree to participate in the study. If the participant was unable to decide, this form was presented to their legal representatives. In addition to the clinical examination, the medical records of these patients were analyzed and data related to gender, age, systemic conditions, presence, or absence of oral lesions, and medication in use were collected and categorized later in an Excel spreadsheet prepared by the researchers.

The length of stay in the ICU was classified according to the Kanban scale, which divides patients into three categories: Kanban I, up to 5 days; Kanban II, 5 to 10 days and Kanban III, over 10 days (MASSARO; MASSARO, 2017). Regarding the inclusion criteria for the present investigation, only individuals over 18 years of age were considered eligible. Children under the age of 18 were excluded from the research protocol.

Two trained examiners evaluated the patients by investigating for possible pathologies present in the oral mucosa, using a wooden spatula and sterile gauze under the artificial light of the ICU. During the examination, lesions that commonly develop on the oral mucosa, such as gingival hyperplasia, candidiasis, hyperkeratosis and aphthous lesions, were investigated.

For data collection and analysis, Microsoft Excel software was used to build a data base, specifically designed for the study.

For the quantitative variable (age), values corresponding to the arithmetic mean were obtained. With regard to qualitative variables (gender, origin, and medical and dental history), data were obtained from a one-dimensional frequency table, from which the respective percentages were identified. 


\section{RESULTS}

Seventy-three patients were assessed. Thirty-three (45.2\%) patients were male, while forty (54.7\%) were female. More than half of the research sample was between 50 and 80 years of age (52\%), with a general average age of 58.2 years.

Only $3(4 \%)$ participants did not present any tooth loss, while 70 (96\%) exhibited some type of edentulism, either partial or total. Regarding the presence of orotracheal intubation, it was observed that 28 (39.7\%) participants required this type of respiratory support.

The length of stay in the ICU was classified according to the Kanban scale, as shown in Table 1. We found that $37(50.6 \%)$ patients remained in the ICU for up to 5 days; however, the period of stay was extended up to 10 days for 12 (16.4\%) patients, and even more for 23 (31.5\%) patients.

Table 1 - Classification of patients according to the length of stay in the general ICU (Kanban). Roberto Santos General Hospital, Salvador, Bahia, 2018.

\begin{tabular}{lc}
\hline Kanban classification & Patients (n; \%) \\
\hline Kanban I (up to 5 days) & $37(50.6 \%)$ \\
Kanban II ( 5 to 10 days) & $12(16.4 \%)$ \\
Kanban III (over 10 days) & $23(31.5 \%)$ \\
\hline
\end{tabular}

Source: Own authorship

The reasons for admission to the ICU were diverse (Table 2). Twenty-two (30.1\%) patients only completed the usual postoperative period (30.1\%), while similar percentages were recorded for patients with a clinical history of stroke, infections and sepsis ( $n=12 ; 16.4 \%)$. Ten (13.6\%) individuals had a decreased level of consciousness and the most frequent comorbidities were Systemic Arterial Hypertension ( $n=27 ; 36.9 \%$ ) and Diabetes Mellitus ( $n=$ 16; $21.9 \%)$. Many other clinical conditions were stated as a reason for admission to the general ICU, such as neoplasms, Ludwig's angina, pulmonary thromboembolism, infarction, neuropathies, and liver diseases.

Table 2 - Clinical conditions associated with the patients' admission to the General ICU. Roberto Santos General Hospital, Salvador, Bahia, 2018.

\begin{tabular}{lc}
\hline $\begin{array}{l}\text { Reason for admission to the Ge- } \\
\text { neral ICU }\end{array}$ & Patients (n; \%) \\
\hline Postoperative period & $22(30.1 \%)$ \\
Stroke & $12(16.4 \%)$ \\
Infections and sepsis & $12(16.4 \%)$ \\
Decreased level of consciousness & $10(13.6 \%)$ \\
Other & $17(23.5 \%)$ \\
\hline
\end{tabular}

Source: Own authorship

Intra-oral physical examination revealed that the main soft tissue injuries and oral conditions presented by the study sample were tongue-coating in 30 patients (41\%) and ulcerations in the oral mucosa caused by trauma or dehydration in 14 individuals (19.1\%). The occurrence of pseudomembranous candidiasis $(n=6 ; 8.2 \%)$, dehydration of the lips and mucosa ( $n=14 ; 26 \%)$, and angular cheilitis $(n=7 ; 9.5 \%)$ was additionally recorded (Table 3$)$.

Table 3 - Oral lesions found during intra-oral physical examination on patients admitted to the General ICU, Roberto Santos General Hospital, Salvador Bahia, 2018.

\begin{tabular}{lr}
\hline Findings & Patients (n; \%) \\
\hline Tongue-coating & $30(41 \%)$ \\
Oral mucosa ulcerations (trauma or dehydration) & $14(19.1 \%)$ \\
Pseudomembranous candidiasis & $6(8.2 \%)$ \\
Dehydration of the lips and mucosa & $14(26 \%)$ \\
Angular cheilitis & $7(9.5 \%)$ \\
Other (hyperplasia, fibroma, periodontal disease) & $6(8,2 \%)$ \\
\hline
\end{tabular}

Source: Own authorship

With regard to the association of changes and oral lesions evidenced by the research sample with the length of stay in the general ICU, it was observed that of the 23 (31.5\%) patients with more than 10 days of hospitalization, $6(26 \%)$ presented pseudomembranous candidiasis. This clinical condition was not seen in patients with a shorter hospital stay. We also found that of the 14 (19.1\%) patients who exhibited ulceration in the oral mucosa, 9 (64\%) of them required mechanical ventilation as a respiratory support.

\section{DISCUSSION}

Hospital dentistry is a recent practice in the Brazilian context, with hygiene protocols and oral care still poorly defined. The literature provides different studies on the definition of a protocol that can cover the needs of these patients (HSU et al., 2010; DESCHEPPER et al., 2018; KHANCHEMEHR et al., 2018) However, research is usually focused on the scope of nursing (ALJA'AFRESH; MOSLEH; HABASHMEH, 2018; DESCHEPPER et al., 2018). In this sense, the present study aimed to outline the profile of a patient population in the general ICU of a public hospital, especially with regard to the occurrence of possible lesions in the oral cavity.

It was observed that most of the sample comprised female patients with a mean age of 58.2 years. In a study by Cruz, Morais and Trevisani (2014), the authors reported similar findings when evaluating a population of 35 patients from a hospital located in Barretos, São Paulo. Other authors have also confirmed the greater number of female patients in the general ICU (LEROY et al., 2009; EUZÉBIO et al., 2013; SANTOS; CUBA, 2018), although the average age found was lower than that observed in the present investigation (BAEDER et al., 2012; CRUZ; MORAIS; TREVISANI, 2014; SANTOS; CUBA, 2018).

In the present study, authors investigated for possible co-morbidities that patients had prior to their admission to the ICU, as well as the reason for hospitalization. A study by Damascena et al. (2017), collected data regarding the 
diseases presented by patients at the time of admission to the ICU. Respiratory complications (58.4\%), sepsis (10.7\%), cardiopulmonary disorders (10.7\%), and diabetes mellitus (6.2\%) were identified as the most frequent health problems. These data differ from the reality shown by the sample of our research, since we observed higher percentages of hypertension (36.9\%) and metabolic syndromes (21.9\%). With regard to the reason for admission to the ICU, we noticed that the most usual justifications were related to postoperative care, cardiovascular changes and septicemia.

In the last five years, no studies were published relating the length of stay, measured by the Kanban classification, with the oral conditions presented by patients admitted to the ICU. However, we were able to identify that there is, in fact, a relationship between the presence of Candida infection and prolonged time of stay in hospital units. The average duration between the moment of admission to the ICU and candidemia is between 19 and 22 days (LEROY et al., 2009; EGGIMANN; BILLE; MARCHETT, 2011). In the present study, patients who exhibited pseudomembranous candidiasis had been hospitalized for more than 10 days (Kanban III), and this infection was not diagnosed in patients with periods of stay in the ICU inferior to this (Kanban I and Kanban II).

Additionally, it was possible to suggest a possible association between the presentation of traumatic ulcers and the use of mechanical ventilation, since $64 \%$ of the patients who required orotracheal intubation had ulcerated lesions in the mucosa. Damascena et al. (2017), identified an equivalent result in their study; the prolonged use of orotracheal intubation caused a reduction in salivary flow, as the oral cavity remains open for long periods, and consequently can present mucosal lesions.

Moreover, according to Damascena et al. (2017), the presence of biofilm on the back of the tongue was reported in $43.8 \%$ of the patients analyzed in their study. This result is similar with and corroborates the present study, since the occurrence of tongue coating was manifested in $41 \%$ of the patients, indicating poor oral care provided by the hospital dentistry team.

Among the limitations found in this study, we can highlight the fact that intubated patients were not provided of a complete clinical analysis of the oral cavity, tongue and palate, mainly. In addition, the lighting offered by the beds of intensive care units is not enough to access the oral cavity efficiently. This fact demonstrates once again the importance of dental surgeons in hospital ICUs, since an efficient instrumentation makes oral clinical exams more accurate and, consequently, the care for these patients. Another limitation was the sample size, as only 73 patients were included in the study due to the short time of data collection. The authors strongly recommend the development of additional studies with a larger number of participants and that allow establishing cause and effect associations between variables.

Hospital dentistry is still a recent context in hospital ICUs. Thus, dental surgeons are not responsible for the provision of oral hygiene, which contributes to biofilm colonization, fungal infections, and lesions in the oral mucosa. The immune system of ICU patients is often compromised, further supporting the involvement of oral manifestations. There is a great diversity of protocols directed to the oral care of ICU patients, including chlorhexidine as the main chemical agent used to control the oral biofilm (HSU et al., 2010; DESCHEPPER et al., 2018; KHANCHEMEHR et al., 2018).

However, its use still generates controversies in the literature; as demonstrated in a study by Deschepper (2018), chlorhexidine could not reduce the risk of developing nosocomial pneumonia in non-cardiac patients. Another study carried out at the University of Kerman, in Iran, compared the use of chlorhexidine and green tea for mouthwashes of ICU patients, and revealed similar effects regarding pharyngeal bacterial colonization (KHANCHEMEHR et al., 2018). Thus, there is an urgent need to establish a unique oral care protocol for the population of patients admitted to the ICU.

\section{CONCLUSIONS}

The present study provided an assessment of the oral health of critically ill patients who do not have efficient dental care and oral hygiene in the general ICU. Although oral health is delegated to other health professionals, such as nurses and nursing assistants, the intervention of dental surgeons could be of great value to these individuals, considering their extensive professional training focused on the study of lesions of the stomatognathic system.

Through this research, it was possible to identify the most prevalent oral condition and oral mucosa lesions in patients admitted to the general ICU. In this way, we hope to contribute to the adoption of preventive and curative care by dental surgeons who will join the multidisciplinary team in the future.

\section{REFERENCES}

ALJA'AFRESH, M. A.; MOSLEH, S. M.; HABASHMEHS. S. Nurse's perception and attitudes towards oral care practices for mechanically ventilated patients. Saudi Med. J., Ryad, v. 39, n. 4, p. 37-85, 2018.

BAEDER, F.M. et al. Oral Conditions of Patients Admitted to an Intensive Care Unit. Pesquisa Brasileira em Odontopediatria e Clínica Integrada, João Pessoa, v. 12, n. 4, p. 517-520, 2012.

BADIEE, P.; ALBORZI, A.; JOUKAR, M. Molecular assay to detect nosocomial fungal infections in intensive care units. Eur. J. Intern. Med., Amsterdam, v. 22, n. 6, p. 611-615, 2011.

BATISTA, S. A. et al. Oral candidiasis in patients admitted to ICU. Rev. Bras. Odontol., Rio de Janeiro, v. 71, n. 2, p. 176-179, 2014.

BUISCHI, Y. P.; AXELSSON, P.; SIQUEIRA, T. R. F. Controle mecânico do biofilme dental e a prática da promoção de saúde bucal. In: BUISCHI, Y. $P$. Promoção de saúde bucal na clínica odontológica. São Paulo: Artes Médicas, 2000. p. 169-214.

CRUZ, M. K.; MORAIS, T. M. N.; TREVISANI, D. M. Clinical assessment 
of the oral cavity of patients hospitalized in an intensive care unit of an emergency hospital. Rev. Bras. Ter. Intensiva, Rio de Janeiro, v. 26, n. 4, p. 379-383.

DAMASCENA, L. C. L. et al. Factors associated with oral biofilm in ICU patients with infectious diseases. Rev. Odontol. UNESP, Marilia, v. 46, n. 6, p. 343-350, 2017.

DENNESEN, P. et al. Inadequate salivary flow and poor oral mucosal status in intubated intensive care unit patients. Crit. Care Med., New York, v. 31, n. 3, p. 781-786, 2003.

DESCHEPPER, M. et al. Effects of chlorhexidine gluconate oral care on hospital mortality: a hospital-wide, observational cohort study. Intensive Care Med., New York, v. 44, n. 7, p. 1017-1026, 2018.

EFFIMANN, P.; BILLE, J.; MARCHETTI, O. Diagnosis of invasive candidiasis in the ICU. Ann. Intensive Care, New York, v. 1, n. 37, p. 1-10, 2011.

EUZÉBIO, L. F. et al. Activities of a Dental Resident in a Multiprofessional Team Focused on Mother and Child Health Care. ROBRAC, Goiania, v. 21, n. 60, p. 16-20, 2013.

GOMES, S. F.; ESTEVES, M. C. L. Role of the surgeon dentist in ICU: a new paradigm. Rev. Bras. Odontol., Rio de Janeiro, v. 69, n. 1, p. 67-70, 2012.

HSU, S. et al. The effects of different oral care protocols on mucosal change in orally intubated patients from an intensive care unit. J. Clin. Nurs., Oxford, v. 20, n. 7, p. 1044-1053, 2010.

$K A H N$, S. et al. Evaluating the existence of oral infection control in patients admitted in state hospitals in Rio de Janeiro. Ciênc. Saúde Colet.,
Rio de Janeiro, v. 13, n. 6, p. 1825-1831, 2008.

KHANCHEMEHR, Y. et al. Comparison of Green Tea and Chlorhexidine Mouthwash Effects on Bacterial Colonies of Throat Cultures of Patients in ICU. Infection Epidemiology and Microbiology, [s.I], v. 4, n. 2, p. 59-65, 2018.

LEROY, O. et al. Epidemiology, management, and risk factors for death of invasive Candida infections in critical care: A multicenter, prospective, observacional study in France (2005-2006). Crit. Care Med., New York, v. 37, n. 5, p. 1612-1618, 2009.

MASSARO, I.A.C.; MASSARO, A. The Use of Kanban in Care Management: Overcoming Limits. Rev. Adm. Saúde., São Paulo, v. 17, n. 66, p. 1-8, 2017.

MORAIS, T. M. N. et al. Importance of dental work in patients under intensive care Unit. Rev. Bras. Ter. Intensiva, Rio de Janeiro, v. 18, n. 4, p. 412-417, 2006.

SÃO PAULO. Câmara dos Deputados. Projeto de Lei no 363, de 2011, que estabelece a obrigatoriedade da presença de profissionais de odontologia nas unidades hospitalares e dá outras providências. p. 1-4, 2011.

SANTOS, A. T.; CUBA, L. F. Dental profile in ICU patients of a southwestern Paraná Oncologic Hospital. Arq. Ciências Saúde UNIPAR, Umuarama, v. 22, n. 2, p. 75-80, 2018.

SCHLESENER, V. R. F; ROSA, U, D.; RAUPP, S. M. M. O cuidado com a saúde bucal de pacientes em UTI. Cinergis, [s.I], v. 13, n. 1, p. 73-77, 2012.

Submetido em: 04/05/2020

Aceito em: 28/05/2020 